\title{
THE ROLE OF HOTELS HUMAN RESOURCES DEPARTMENT IN REHABILITATING STAFF TO BE A GREEN HOTEL GRADE "A Comparative Study between Egyptian and Moroccan Hotels" AHMED MOHAMED ATEF AHMED
}

The Higher Institute for the specific studies, El-Giza,

\begin{abstract}
The research objective is to shed light on the concept of green hotels, on the requirements of hotels to be "green ", and on the role of human resources department and its policy in hotels to direct workers to the importance of green management. A survey was carried out on twenty seven hotels in Egypt, Cairo, Alexandria, South Sinai, Red sea, Luxor and Aswan; beside other twenty seven hotels in Morocco , Casablanca, Marrakesh, Essaouira, Fez, Agadir, Rabat and Tangier which implement the green hotel concept. It mainly focused on obtaining information if the hotel has environmental protection methods or if it has a green management (saving water and energy, reducing wastes). The major findings showed that eighteen of the Moroccan hotels apply the concept of green management, against 11 Egyptian hotels. The study recommends the need to activate the green hotels concept in Egypt and, especially after the great interest of the European countries in "green hotels".
\end{abstract}

Key Words: senior manager, Sustainability, Green Hotels. In-depth interview.

Introduction and background

There are six billion people on earth who need food, clean water, clothing, shelter, good health and other basic amenities. All these services are obtained from the environment - from ecosystems, to be specific. Thus, there is a very urgent need for responsible and sustainable use of biological resources that reduces, re-uses and recycles. Ironically, although human well-being is so intimately inter-linked with ecosystems, in seeking to improve their well-being, humans are over-using, over-stressing and over-exploiting biological resources and damaging the environment. By doing so, they are destroying the very resources they need to improve the quality of their lives.

Bohdanowicz and Martinac (2007) indicated that hotel industry worldwide is becoming more and more concerned with environmental issues. $75 \%$ of environmental pollution caused by hotel industry was from over-consuming energy, water, and materials. The waste water, fume, and materials discharged during the operation would cause negative impacts on our environment. Thus, without proper design and plan, environment would be impacted in an unwanted way. The concept of environment protection and energy saving can induce green management into hotel facility construction. If hotel industry can put the idea of green management into practice, not only can it benefit environmental and ecological protection, but it would also reduce hotel operation cost. Moreover, green marketing can attract consumers who are in favor of the same idea as well.

The United Nations World Tourism Organization suggests sustainable tourism should:

Make optimal use of environmental resources

Help to conserve natural and living cultural heritage and diversity.

Respect the social-cultural authenticity of host communities.

In a similar way, hotels cannot and should not oblige guests to use, for example, recycling bins for paper waste. The hotel can provide environmentally friendly facilities and promote awareness of sustainable practices, but it is the decisions made by individual guests and individual staff members to cooperate that will determine the success or failure of these initiatives.

\section{Review of Literature}

Definition of Green Hotel

Australia (2007) proposed that the idea of green hotel is to provide natural accommodation and facility including green services, green products, and comfortable environment. Lee Ni (2002) also suggested that a green hotel is that which provides both facilities and services with the idea of environmental protection. 
Green hotels in the green Mountain State (2006) defined a green hotel as "a hotel that makes efforts on create a fine environment and encourages its staff and customers to participate in the activity, also needs to observe carefully each operation to reduce impacts on environment".

Alexander (2011) mentioned that Green Hotels are environmentally-friendly properties whose managers are eager to institute programs that save water, save energy and reduce solid waste, while saving money to help protect our one and only earth.

\section{Energy Efficiency}

Clark (2000) pointed out that a large hotel can have thousands of individual light bulbs and fluorescent fixtures and may use 30 percent of its total electricity on lighting. By upgrading in guest rooms, common areas and behind-the scenes areas, a hotel can see immediate and consistent savings with no impact on the overall guest experience. The housekeeping personnel can assist in saving energy in a number of ways like: resetting thermostats when cleaning a room, reporting water leaks, and turning off lights.

\section{Water Conservation}

Water is an increasingly scarce resource in most parts of the world and the United Nations estimates that more than half the world population could be living in severely water stressed areas by 2032 .

Schroeder (2004) illustrated the effective conservation of water in all departments of the hotel, across all levels. The extent to which water is recycled and utilized is also considered an important factor. Again, all employees are expected to be well-versed in water conservation operations of the hotel. Water used in hotels and other lodging businesses accounts for approximately 15 percent of the total water use in commercial and institutional facilities. The largest uses of water in hotels are restrooms, laundry operations, landscaping, and kitchens. Operating costs and environmental impacts are influenced by water use.

High-performing water-using equipment and fixtures are now available that use at least 20 percent less water than conventional models. Hotel owners can also benefit by employing water-efficient practices through operational improvements and upgraded equipment. For example, instituting linen and towel reuse programs in guest rooms can help reduce the loads of laundry by 17 percent. Adopting water-efficient practices will allow hotel owners to meet the demands of green hotels. (Newman, 2008)

\section{Waste Management}

According to the World Bank 64\% of solid waste in Egypt is improperly disposed of, thereby can have serious repercussions on the environment. Even garbage that is properly disposed of can be an environmental risk as the world's landfills rapidly run out of room and can take many years to biodegrade For instance a plastic bag you pick up from a supermarket could take up to 200 years to degrade.

Matzler and Renzl (2007) indicated that reduction of waste or waste minimization is a priority for all of us. If waste is reduced it becomes manageable. Reducing waste means buying and consuming less or even buying in bulk to reduce packaging waste. Large amounts of waste products are generated in the administration and reception areas of a hotel on a daily basis. There are three methods to manage waste accumulation: reduce, reuse and recycle.

\section{Certifications for Sustainable Tourism}

First of all, there are over 800 different green certifications offered around the world so far. Hotel industry makes great impacts on the environment; therefore, certifying hotels for their environmental protection efforts has become a trend. It can help business obtain benefit through abiding by the eco-criteria and giving small business opportunities to get a place in the market. Many governments and associations are making efforts to plant the spirit of environmental protection into hotel management, such as United Nations' Green leaf Eco-rating Program (UNESCO), and International Hotel Association's “ The Hotels' Environmental Charter”(Chen, 2000).

Önal et al. (2007) stated that Tourists are now becoming more aware of sustainability-related issues. Their purchasing decisions are now increasingly based on environmental and ethical grounds. The trend of green hotel has been followed for years in other countries. Globally-recognized programs can provide extensive media support to a hotel internationally, whereas local or regional programs can provide a network of likeminded local hotels and tour operators. Hotels may benefit from having multiple certifications, especially as tour operators may require certain certifications and not others. Furthermore, once standards for one certification are in place, it will be easier to obtain other certifications. It is up to hotel managers to choose the appropriate certification that will give the most benefit to the hotel and its surroundings. 


\section{Human Resources Functions As an Essential Tool to Rehabilitate Hotel Staff for the Green Hotels Concept}

\section{Employees Awareness}

Hotel managers indicate that our perception needs to be adjusted and suitable management

Criteria need to be set up. Everybody needs to know what his responsibility is and updated record should be kept all the time. All of these are not easy and need to be done by entire employees' efforts. Nevertheless, most managers consider this aspect as the easier one, although management system and the outcome might be diversified among different hotels. Hotels need to make efforts on staff's professional training, employees' recognition, and cooperation. If the entire above can be properly executed, managed, and monitored, the quality of the entire environment will be enhanced significantly. Not only can hotels get customers' approval for their service quality, but its competitiveness will increase as well. (Mullins, 1998)

Anderson and Sullivan (2003) reported that Employees' personal behaviors need to be changed when a hotel is trying to promote green measures and increase its efficiency. Hotels need to train, teach, and offer rewards to employees who provide useful comments on environmental improvement. Hotels also need to make their employees fully understand why they implement the green policy, and what they can do to reduce energy consumption and reduce environmental pollution through personal behaviors. Training employees, making them understand, cooperate, carry out, and achieve the goals are all challenges hotels might encounter. When conducting training, hotels' managers need to consider the possibility of its proper conduct and the potential of employee's cooperation after the training implementation. The goal of employee training is to reduce impacts on environment and energy consumption in the business life cycle. Training can also maintain service quality to meet customers' needs and attract more customers who have better idea about environmental protection. Inside the hotel, training can increase employees' approvals toward the company, which means not only can green policy enhance employees' behaviors to protect the environment, but it can continuously advance the business to the goal of an excellent environment. In addition, training can make employees fully understand the concept of environmental protection, so that they might carry out the idea in both work and living environment.

\section{Consumer Awareness}

Koys (2003) reported that Consumers must recognize the fact that environmental protection is to keep the last piece of clean land for our future generations. Therefore, selecting green hotel is the only choice and the government should try harder to promote the idea of environmental protection, so people's willingness of selecting green hotels will be increased. Not only can it remain our living environment and living quality, it would also make hotels speed up to transform to green hotels through consumers' power. Hotel managers indicated that other than consumers' cooperation, the effectiveness of environmental protection guidance also depends on the customers' acceptance and perception. For example, customers might think recycling is not handy and bothersome. For sure, room rate is the major concern for customers, but with the same price rate, customers can easily recognize the hotel's effort and gain more knowledge about green hotel. Therefore, they might come back again next time. Besides, hotels can place brochures or notes of environmental protection inside the room in case customers are not aware of hotels' efforts on environmental protection. However, hotel managers must remember that they should not ask Customers to take the full responsibility without getting any benefit. For example, hotels can share the benefit with customers who follow hotels' green measure. Thus, when customers agree to not change clean towels, hotels can provide a certain amount of discount to them. In conclusion, hotels can save operational cost and reduce the entire societal cost through carrying out green management. Beside building better reputation and popularity, and brand effect; all form invisible assets that the hotels can gain. Meanwhile, through self-examination, hotels can reach the standard of green hotel and strengthen its key competitiveness towards the environmental protection and highlights of hotels' features.

\section{Research Objectives}

The research objective is to shed light on the grade of green hotels which aims to reduce damage to the environment, on the requirements for hotels to get the grade of this new green hotels direction, and on the role of human resource department in hotels to direct workers to the importance of the special management practices in terms of enhancing the efficiency of energy use in hotels, how to conserve water and the importance of attempt reducing wastes.

\section{Research Methodology}

The research was accomplished through a survey study on twenty seven Moroccan hotels to know which of them implement the green hotel concept in comparison with Egyptian Hotels which implement the green hotel concept by using Paired-Sample T Test. Interviews were conducted with twenty seven responsible senior Managers from various hotels in Egypt. The data collected were analysed using SPSS version 16. A comparison was carried out among hotels 
towards green hotel concept by using the frequency analysis. The purpose of these interviews was to know and identify the perspectives of hotel managers towards green hotels concept and to set recommendations which lead managers and staff to the concept of the green management.

\section{Case study}

\section{Egypt (Mövenpick Resort \& Spa - El Gouna)}

The upscale five star Mövenpick Resort \& Spa El Gouna is located directly on the Red Sea and features an extensive beach frontage. The relaxing atmosphere combined with extensive facilities invites to enjoy an unparalleled holiday in Egypt: World class diving in the Red Sea at its doorstep, the challenging18-hole El Gouna golf course nearby, a professional kite surf station directly on the hotel's beach, Spa for the ultimate wellness experience, a state of the art conference centre, plenty of attractions for families with children and special facilities for the physically challenged will cater for every guest need to experience a perfect stay.

\section{Table1: Case Study of Egyptian Hotel.}

\begin{tabular}{|l|l|}
\hline Green Actions & Positive Impacts \\
\hline $\begin{array}{l}\text { New dish washing machine that incorporates } \\
\text { water reuse. This system reuses water from the final } \\
\text { rinse cycle to use in the initial washing stage for the } \\
\text { next load of dishes }\end{array}$ & $\begin{array}{l}\text { Cost of dishwasher }=50000 \$ \\
\text { dishwasher } \$ \\
\mathbf{= 9 0} \text { Litres per wash } \\
\mathbf{= 3 2 8 5 0 0} \text { Litres per year }\end{array}$ \\
\hline
\end{tabular}

Morocco (l'amphitrite palace Hotel-Rabat)

L' Amphitrite Palace Resort \& Spa is located in Skhirat Beach, just a 20-minute drive from Rabat and 1-hour drive from Casablanca. The property overlooks the Atlantic Ocean. The resort offers a private beach, world class rooms and spacious suites with luxurious furniture and elegant design. The spa offers beauty and body treatments, a hydro pool, outdoor swimming pool, outdoor hot tub, fitness center and 13 private treatment rooms. L'Amphitrite Palace Resort \& Spa is a luxury hotel distance just 20 minute's drive from Golf Dar Essalam.

\section{Table 2: Case Study of Moroccan Hotel}

\begin{tabular}{|l|l|}
\hline Green Actions & Positive Impacts \\
\hline $\begin{array}{l}\text { Water from air conditioners is being re-used in } \\
\text { the laundry for steam irons }\end{array}$ & $\begin{array}{l}\text { Reuse of water from air conditioners has reduced } \\
\text { the need to purchase distilled water by } 960 \text { litres } \\
\text { thereby reducing water wastage by the same } \\
\text { amount and saving the hotel Rs.38,500 (approx } \\
€ 250) \text { per year. }\end{array}$ \\
$\begin{array}{l}\text { From January } 2010 \text { to September } 2010(9 \text { months) } \\
\text { ainen is line dried on sunny days } \\
\text { worth Rs.107,500 (€700) and Gas worth } \\
\text { Rs. } 121,500(€ 800) \quad \text { and }\end{array}$ \\
\hline
\end{tabular}

\section{Data Analysis}

The Survey Study Results.

A survey was carried out on twenty seven hotels in Egypt in Cairo, Alexandria, South Sinai, Red sea, Luxor and Aswan, beside twenty seven hotels in Morocco in Casablanca, Marrakesh, Essaouira, Fez, Agadir, Rabat and Tangier (Table 7). Contacts with the Moroccan hotels were conducted through emails, phone calls and websites, while in Egypt contacts were conducted through personal visits, phone calls, emails and websites. 
The major findings of this survey showed that eighteen of the Moroccan hotels apply the concept of the green management, (67\% of the Moroccan investigated hotels) as against eleven hotels in Egypt ( $40 \%$ of the Egyptian investigated hotels). The findings show that hotels which apply green management achieved a higher occupancy. This finding agrees with Önal et al. (2007) who stated that tourists are now becoming more educated regarding sustainability-related issues and their purchasing decisions are now increasingly based on environmental and ethical grounds.

The results of interview with senior managers in Egyptian hotels.

The interview with senior managers was conducted through personal visits, phone calls, emails, fax and websites. It mainly focused on obtaining information if the hotel has environmental protection methods or if it has a green management to save water and energy, reduce wastes and environmental impacts through the participation of staff and customers. It consists of fifteen questions (Table3). 


\begin{tabular}{|c|c|c|c|c|c|c|c|}
\hline Hotel & Region & $\begin{array}{l}\text { Occ. } \\
\text { Perc }\end{array}$ & $\begin{array}{l}\text { green } \\
\text { policies }\end{array}$ & Hotel & Region & $\begin{array}{l}\text { Occ. } \\
\text { Perc }\end{array}$ & $\begin{array}{l}\text { green } \\
\text { policies }\end{array}$ \\
\hline Sunrise Select Garden Beach Resort \& Spa. & \multirow{10}{*}{ 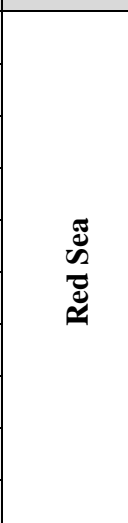 } & $71 \%$ & Yes & Hotel Paradis Plage & \multirow{7}{*}{ : } & $86 \%$ & Yes \\
\hline Sentido Mamlouk Palace Resort. & & $68 \%$ & No & Hotel Atlantic Palace & & $68 \%$ & No \\
\hline Arabella Azur Resort. & & $82 \%$ & No & Decameron Takfout Resort. & & $85 \%$ & Yes \\
\hline Citadel Azur Resort Sahl Hasheesh. & & $77 \%$ & No & Iberostar Founty Beach Resort & & $87 \%$ & No \\
\hline Sunrise Select Royal Makadi Resort. & & $76 \%$ & Yes & Hotel Almoggar Garden Beach & & $84 \%$ & Yes \\
\hline Stigenberger El dau Beach. & & $58 \%$ & yes & Robinson Club & & $89 \%$ & Yes \\
\hline Arabia. & & $65 \%$ & No & Hotel Sofitel Agadir Thalassa Sea \& Spa & & $90 \%$ & Yes \\
\hline Sindbad Club. & & $89 \%$ & No & Hotel Mazagan Beach and Golf Resort. & \multirow{3}{*}{ 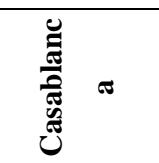 } & $82 \%$ & Yes \\
\hline Mövenpick Resort \& Spa - El Gouna & & $96 \%$ & Yes & Hotel Casablanca Le lido Thalasso \& Spa. & & $77 \%$ & Yes \\
\hline Hilton Hurghada Resort. & & $92 \%$ & No & Hotel Sofitel Casablanca Tour Blanche & & $88 \%$ & Yes \\
\hline Savoy Sharm El Sheikh Hotel. & \multirow{6}{*}{ 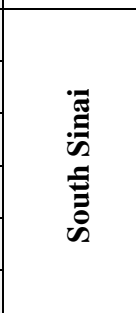 } & $93 \%$ & Yes & Atlas Essaouira \& Spa essaouira Resort. & Essaouira & $83 \%$ & No \\
\hline Holiday Village. & & $87 \%$ & No & Palais Medina \& Spa Resort & \multirow{2}{*}{$\underset{I}{\mathbb{N}}$} & $84 \%$ & Yes \\
\hline Coral Sea Imperial (Sensatori). & & $84 \%$ & No & Ramada Hotel & & $85 \%$ & No \\
\hline Coral Sea Splash. & & $82 \%$ & No & Hotel Palmeraie Palace & \multirow{10}{*}{ 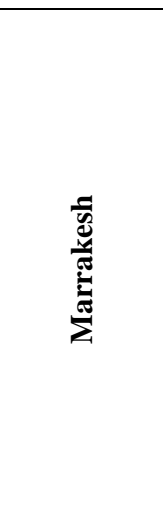 } & $73 \%$ & Yes \\
\hline Iberotel Il Mercato. & & $90 \%$ & yes & Es Saadi Gardens \& Resort - Palace & & $63 \%$ & Yes \\
\hline Domina Coral Bay Hotel, Resort, Spa \& Casino. & & $83 \%$ & No & Palais Faraj Suites \& Spa Resort & & $75 \%$ & No \\
\hline Steigenberger Luxor. & \multirow{4}{*}{ 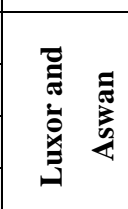 } & $88 \%$ & Yes & Four Seasons Resort Marrakech. & & $93 \%$ & Yes \\
\hline Orchid Floating Hotel Aswan. & & $69 \%$ & No & Sirayane Boutique Hotel \& Spa & & $82 \%$ & Yes \\
\hline Cataract. & & $90 \%$ & No & Le Meridien N'fis marakesh Hotel. & & $88 \%$ & Yes \\
\hline Tulip Floating Hotel Aswan. & & $66 \%$ & No & Ksar Char-Bagh marakesh Hotel. & & $66 \%$ & No \\
\hline Grand Nile Towers. & \multirow{6}{*}{ Uี } & $92 \%$ & Yes & Kenzi Club Agdal Medina & & $74 \%$ & Yes \\
\hline Marriot El Zamalek. & & $90 \%$ & Yes & Hôtel Du Golf Marrakech & & $68 \%$ & No \\
\hline Fairmont Airport. & & $89 \%$ & No & Jardin d'Inès By Christophe Leroy & & $72 \%$ & Yes \\
\hline Four Seasons Nile Plaza. & & $92 \%$ & Yes & Le Dawliz Hotel and Spa Resort & \multirow{3}{*}{ 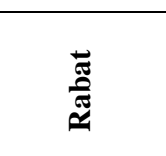 } & $82 \%$ & No \\
\hline Novotel 6 October. & & $84 \%$ & No & l'amphitrite palace Hotel. & & $86 \%$ & Yes \\
\hline Sheraton El montazah. & & $93 \%$ & Yes & La Tour Hassan Hotel. & & $66 \%$ & No \\
\hline Mercure. & Alex & $88 \%$ & No & Mövenpick Hotel \& Casino Tangier. & Tangier & $91 \%$ & Yes \\
\hline
\end{tabular}




\section{Findings}

\section{Analysis of the Managers Answers:}

\begin{tabular}{|c|c|c|c|}
\hline Question 1 & & Freq & Percent \\
\hline \multirow{3}{*}{$\begin{array}{c}\text { Does your hotel have any environmental policies / energy conservation } \\
\text { practices, such as recycling waste and energy saving light bulbs }\end{array}$} & yes & 7 & $25.90 \%$ \\
\cline { 2 - 4 } & NA & 4 & $59.30 \%$ \\
\cline { 2 - 4 } & Total & 27 & $14.80 \%$ \\
\hline Analysis & \multicolumn{2}{|c|}{$100 \%$} \\
\hline
\end{tabular}

Above data shows that about $26 \%$ of the managers mentioned that they have environmental policies and energy

conservation practices in their hotels, $59 \%$ said that they don't have any of them in their hotel and about $15 \%$ stated that it is not applicable in their hotel.

\section{Question 2}

Do you use any used recyclable products to make compost for hotel gardens?

\begin{tabular}{|c|c|c|}
\hline & Freq & Percent \\
\hline yes & 24 & $88.90 \%$ \\
\hline no & 3 & $11.10 \%$ \\
\hline Total & 27 & $100 \%$ \\
\hline
\end{tabular}

\section{Analysis}

In regards to the usage of the recyclable products, about $89 \%$ of the hotel managers mentioned that they use these products while about $11 \%$ stated that they do not use these products.

\begin{tabular}{|c|c|c|c|}
\hline Question 3 & & Freq & Percent \\
\hline \multirow{2}{*}{ Do you have a linen and towel reuse program? } & yes & 21 & $77.80 \%$ \\
\cline { 2 - 4 } & no & 6 & $22.20 \%$ \\
\cline { 2 - 4 } & Total & 27 & $100 \%$ \\
\hline Analysis & & \\
\hline
\end{tabular}

In terms of Having a linen and towel reuse program, about $78 \%$ stated that they use these programs while $20 \%$ said that they do not use them.

\section{Question 4}

Do you have any recycling facilities available for guests such as separate paper, glass, plastic and general recycling bins?

\begin{tabular}{|c|c|c|}
\hline & Freq & Percent \\
\hline yes & 18 & $66.70 \%$ \\
\hline no & 9 & $33.30 \%$ \\
\hline Total & 27 & $100 \%$ \\
\hline
\end{tabular}

\section{Analysis}

Concerning the availability of recycling facilities, about $67 \%$ of them have recycling facilities. $33 \%$ of them do not have any recycling facilities.

\section{Question 5}

Does your hotel have any environmentally friendly vehicles for staff or guests such as smaller mini buses, bicycles, electric cars etc.?

\section{Analysis}

In terms of having environmentally friendly vehicles for staff or guests, about $52 \%$ of them have environmentally friendly vehicles for staff or guests. On the other side, about $48 \%$ of them do not have any environmentally friendly vehicles.

\section{Question 6}

Does your hotel use standard mechanical room keys?

\begin{tabular}{|c|c|c|}
\hline & Freq & Percent \\
\hline yes & 14 & $51.90 \%$ \\
\hline no & 13 & $48.10 \%$ \\
\hline Total & 27 & $100 \%$ \\
\hline
\end{tabular}




\begin{tabular}{|c|c|c|c|}
\hline Question 7 & & Freq & Percent \\
\hline \multirow{3}{*}{ Is your left-over food disposed of with normal waste? } & yes & 18 & $66.70 \%$ \\
\hline & no & 9 & $33.30 \%$ \\
\hline & Total & 27 & $100 \%$ \\
\hline \multicolumn{4}{|l|}{ Analysis } \\
\hline \multicolumn{4}{|c|}{ Concerning the disposition of left-over food with normal waste, $67 \%$ of them said yes whilst $33 \%$ said no. } \\
\hline Question 8 & & Freq & Percent \\
\hline \multirow{3}{*}{ Does your hotel use linen rather than paper napkins in the restaurants? } & yes & 26 & $96.30 \%$ \\
\hline & no & 1 & $3.70 \%$ \\
\hline & Total & 27 & $100 \%$ \\
\hline \multicolumn{4}{|l|}{ Analysis } \\
\hline
\end{tabular}

Concerning the usage of linen rather than paper napkins, 96 of the hotel managers said they use them while about $4 \%$ do not use them

\begin{tabular}{|c|c|c|c|}
\hline Question 9 & & Freq & Percent \\
\hline \multirow{2}{*}{ Do you have economy low flow toilets and shower heads? } & yes & 20 & $74.10 \%$ \\
\cline { 2 - 4 } & no & 7 & $25.90 \%$ \\
\cline { 2 - 4 } & Total & 27 & $100 \%$ \\
\hline Analysis
\end{tabular}

In regards to having economy low flow toilets and shower heads, $74 \%$ of them stated that they have them Meanwhile, $26 \%$ of them do not use them.

\begin{tabular}{|c|c|c|c|}
\hline Question 10 & Freq & Percent \\
\hline \multirow{3}{*}{ Do you have a policy on front and back office printing? } & yes & 21 & $77.80 \%$ \\
\cline { 2 - 4 } & no & 6 & $22.20 \%$ \\
\cline { 2 - 4 } & Total & 27 & $100 \%$ \\
\hline Analysis
\end{tabular}

In terms of having a policy on front and back office printing, $78 \%$ agreed that they have policies concerning this issue in their hotel while $23 \%$ do not have any policies.

\begin{tabular}{|c|c|c|c|}
\hline Question 11 & & Freq & Percent \\
\hline \multirow{2}{*}{ Do you use dimmable lighting? } & yes & 18 & $66.70 \%$ \\
\cline { 2 - 4 } & no & 9 & $33.30 \%$ \\
\cline { 2 - 4 } & Total & 27 & $100 \%$ \\
\hline Analysis & \multicolumn{2}{|c}{} \\
\hline Ang
\end{tabular}

Concerning the usage of dimmable lighting, $67 \%$ of them use it, $33 \%$ do not use.

\begin{tabular}{|c|c|c|c|}
\hline Question 12 & Freq & Percent \\
\hline Do you have buffet style restaurants? & yes & 27 & $100.00 \%$ \\
\hline Analysis
\end{tabular}

In terms of having buffet style restaurants, all the hotels have buffet style restaurants

\begin{tabular}{|c|c|c|c|}
\hline Question 13 & Freq & Percent \\
\hline Have the public restrooms in the hotel premises been fitted with taps & yes & 3 & $11.10 \%$ \\
\hline
\end{tabular}




\begin{tabular}{|c|c|c|c|}
\hline \multirow[t]{2}{*}{ which automatically turn off after a certain time? } & no & 24 & $88.90 \%$ \\
\hline & Total & 27 & $100 \%$ \\
\hline \multicolumn{4}{|l|}{ Analysis } \\
\hline \multicolumn{4}{|c|}{$\begin{array}{l}\text { Concerning the public restrooms in the hotel premises been fitted with taps which automatically turn off after a } \\
\text { certain time, } 11 \% \text { of them have it and } 89 \% \text { of them do not use them. }\end{array}$} \\
\hline Question 14 & & Freq & Percent \\
\hline $\begin{array}{l}\text { Would you be interested in joining a special focus group that would } \\
\text { explore Green issues at Egyptian Hotels and promote Green Tourism } \\
\text { awareness? }\end{array}$ & yes & 27 & $100.00 \%$ \\
\hline \multicolumn{4}{|l|}{ Analysis } \\
\hline \multicolumn{4}{|c|}{$\begin{array}{c}\text { Regarding joining a special focus group that would explore Green issues at Egyptian Hotels and promote Greer } \\
\text { Tourism awareness, all of the managers said yes }\end{array}$} \\
\hline \multicolumn{4}{|l|}{ Question 15} \\
\hline \multicolumn{4}{|c|}{ Determine how much do you know about the environmental impact of the products your hotel buys and uses? } \\
\hline \multicolumn{4}{|l|}{ Analysis } \\
\hline \multicolumn{4}{|c|}{$\begin{array}{l}\text { Concerning the above mentioned question, thirteenth managers said that they are fully aware and four Managers } \\
\text { stated that they know the most significant impacts, while two managers mentioned that they know little about this } \\
\text { and eight managers said that they know nothing. }\end{array}$} \\
\hline
\end{tabular}

\section{Recommendations}

- The study recommends to activate the green hotels grade in Egyptian Hotels especially that tourists become more educated on matters related to sustainability and their decision of hotel reservation is based on the environmental and ethical grounds

- There is lack of awareness of green hotels concept and its effect on human being among managers and assistant managers working in hotels. This observation proves the need for more awareness efforts.

- Hotels management in Egypt should direct some of its budgets to save water and energy, reduce wastes and environmental impacts through the participation of staff and customers.

- Hotels management in Egypt should provide staff with continuous free training programs on green hotels organized by the ministry of tourism.

- The Ministry of Tourism should define and reinforce a standard green system with minimum requirements to be applied by hotels in 2020 .

- The Ministry of Environment should establish a specialized managerial unit in each region to deal with environmental crises.

\section{References}

- Alexander,S.(2011) For “The Zero Waste Alliance”. Hospitality Research Journal, 19 (4), pp. 113-127.

- Anderson, E. and Sullivan, M. (2003), "The Antecedents and Consequences of Customer Satisfaction for Firms", Marketing Science, pp. 25-30.

- Australia, E. (2007). Environmental protection programs and conservation practices of hotels in Ankara, Turkey. Tourism Management, 28, 604-614. http://dx.doi.org/10.1016/j.tourman.2006.07.003

- Bohdanowicz, P., Martinac, I. (2007). Determinants and benchmarking of resource consumption in hotelsCase study of Hilton International and Scandic in Europe. Energy \& Buildings, 39(1), 82-95. http://dx.doi.org/10.1016/j.enbuild.2006.05.005

- Chen R. L. (2000). Green Building Rating and Labeling System. International Conference Dissertation of Sustainable Building Environment in the 21st century. Ministry of the Interior Building Research Institute

- Clark, J. (2000), "York Dictionary of Hotels, Tourism, and Catering Management", York Press, Lebanon, p.164.

- Green Hotels Association. (2007). What Are Green Hotels. Retrieved from http://www.greenhotels.com/whatare.htm 
- Green Hotels in the Green Mountain State. (2006). What Is A Green Hotel. Retrieved from http://www.vtgreenhotels.org/whatis.htm

- Koys, D. (2003), "How the Achievement of Human- Resources Goals Drives Performance", Cornell Hotel and Restaurant Administration Quarterly (2003), pp.17-24.

- Lee N. (2002). Green Leaves label for Green Hotel. China Airlines Journal, May, 20-22.

- Matzler K. and Renzl, B. (2007), "Assessing Asymmetric Effects in the Formation of Waste”, Tourism Management 28 (2007), pp. 93-103.

- Mullins, L.J. (1998), "Managing People in the Hospitality Industry”, Third Edition, Longman, Edinburg, pp. $227, .256$.

- Newman, K. (2008). “Green procurement activities: some environmental indicators and practical actions taken by industry and tourism. Environment and Sustainable Development, 1(1), 59-72.

- Önal, Y.; Düzakın, E. and Çiftçi, H. (2007), "System and Its Effects on the Turkish Tourism Sector". Journal of Problems and Perspectives in Management, Vol. 5 No. 3, pp. 269-281

- Schroeder, R.G. (2004), “Operations Management”, second edition, McGraw Hill, New York, pp 133-134.

\section{Websites:}

http://www.greenhotels.com/

http://en.wikipedia.org/wiki/Eco_hotel

http://greentraveling.weebly.com/definition.html

http://www.concepthospitality.com/consultant/ecotel_certification.htm

http://aha.org.au/energy

http://hotelenergysolutions.net/content/ee-improve-equipment-efficiency

www.epa.gov/watersense/commercial.

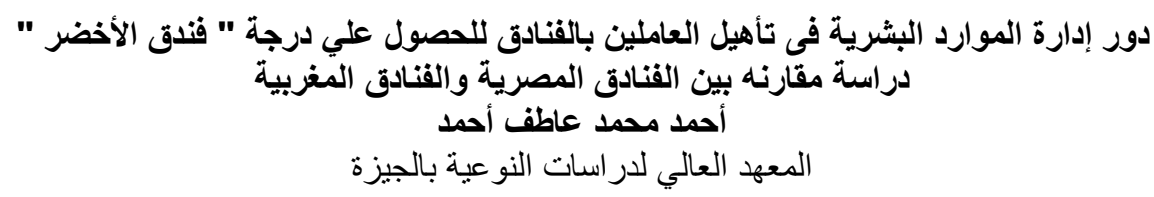

يهدف البحث إلى إلقاء الضوء على مفهوم الفنادق الخضر اء التي تهدف إلى تقليل الأضرار التي تلحق بالبيئة وعلي متطلبات الحصول

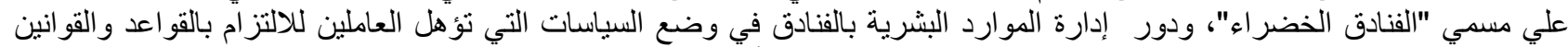

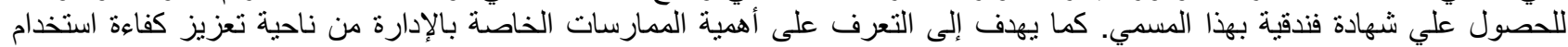

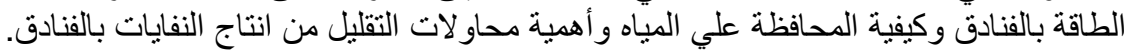

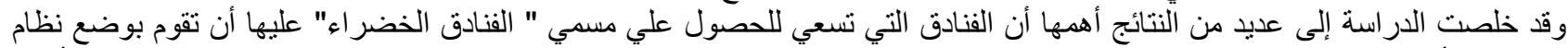

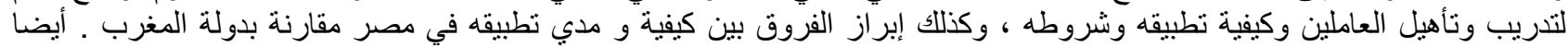

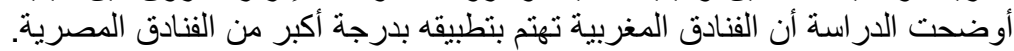

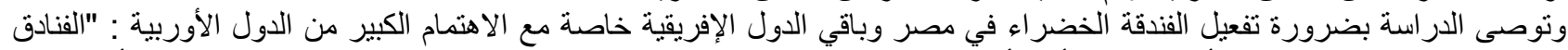

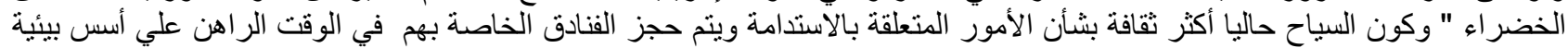

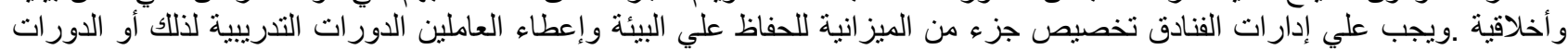

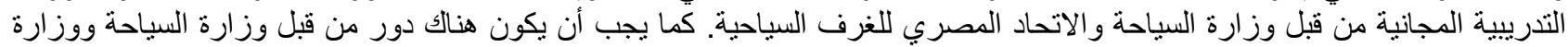

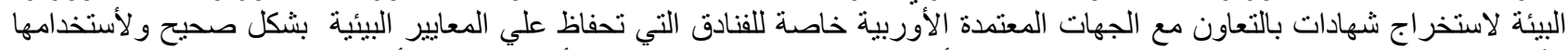

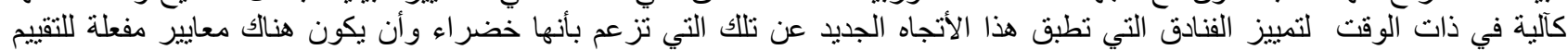

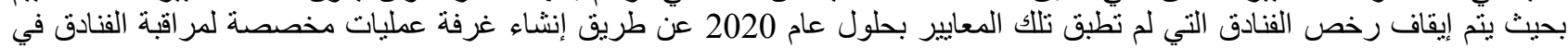

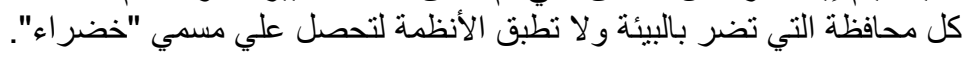

\section{$\underline{\text { Appendix A }}$}

\section{Name of Hotel:}

\section{Name of Contact:}

E-mail address:

\section{Stars:}

\section{Position held:}

Mobile No.: 


\begin{tabular}{|c|c|c|}
\hline Enquiry & Yes & No \\
\hline $\begin{array}{l}\text { 1. Does your hotel have any environmental policies / energy conservation practices, such as } \\
\text { recycling waste and energy saving light bulbs etc? }\end{array}$ & & \\
\hline 2. Do you use any used recyclable products to make compost for hotel gardens? & & \\
\hline 3. Do you have a linen and towel reuse program? & & \\
\hline $\begin{array}{l}\text { 4. Do you have any recycling facilities available for guests such as separate paper, glass, plastic } \\
\text { and general recycling bins? }\end{array}$ & & \\
\hline $\begin{array}{l}\text { 5. Does your hotel have any environmentally friendly vehicles for staff or guests such as smaller } \\
\text { mini buses, bicycles, electric cars etc.? }\end{array}$ & & \\
\hline 6. Does your hotel use standard mechanical room keys? & & \\
\hline 7. Is your left-over food disposed of with normal waste? & & \\
\hline 8. Does your hotel use linen rather than paper napkins in the restaurants? & & \\
\hline 9. Do you have economy low flow toilets and shower heads? & & \\
\hline 10. Do you have a policy on front office and back office printing? & & \\
\hline 11. Do you use dimmable lighting? & & \\
\hline 12. Do you have buffet style restaurants? & & \\
\hline $\begin{array}{l}\text { 13. Have the public rest rooms in the hotel premises been fitted with taps which automatically turn } \\
\text { off after a certain time? }\end{array}$ & & \\
\hline $\begin{array}{l}\text { 14. Would you be interested in joining a special focus group that would explore Green issues as } \\
\text { they relate to Egyptian Hotels and promote Green Tourism awareness? }\end{array}$ & & \\
\hline
\end{tabular}

15. Determine how much do you know about the environmental impact of the products your hotel buys and uses?

$\square$ I am fully aware
$\square$ I know little about this.
I know about the most significant impacts

I know nothing 